* Mestranda em Direito Negocial pela Universidade Estadual de Londrina (UEL); Pós-graduanda em Direito do Estado - Direito Tributário pela Universidade Estadual de Londrina (UEL); Colaboradora nos projetos de pesquisa n. 11797 - "Negócios biojurídicos: as tecnologias e o Direito Civil" e n. 12475 "Contratualização das relações familiares e das relações sucessórias", ambos vinculados à Universidade Estadual de Londrina (UEL); Advogada.

E-mail: melissa.ferrari@uel.br

** Doutora em Direito Civil pela Universidade Federal do Paraná (UFPR); Mestra em Direito Negocial pela Universidade Estadual de Londrina (UEL); Docente do curso de Direito e do Programa de Mestrado e Doutorado da Universidade Estadual de Londrina (UEL); Coordenadora do projeto de pesquisa n. 11797 - "Negócios biojurídicos: as tecnologias e o Direito Civil", vinculado à Universidade Estadual de Londrina (UEL).

E-mail: rita.tarifa@gmail.com

\section{Dignidade Humana E Manipulação Genética: Reflexões Jusfilosóficas ACERCa da ModificaÇão Do Genoma}

\author{
Human Dignity And Genetic Manipulation: \\ JusphilosophicAl ReFlections About GenOME \\ MODIFICATION
}

\section{Melissa Mayumi Suyama Ferrari* Rita de Cássia Resquetti Tarifa Espolador**}

Comocitar:FERRARI, Melissa Mayumi Suyama;ESPOLADOR, Rita de Cássia Resquetti Tarifa. Dignidade humana e manipulação genética: reflexões jusfilosóficas acerca da modificação do genoma. Revista do Direito Público, Londrina, v. 16, n. 3, p. $27-$ 43, dez. 2021. DOI: 10.5433/24157-108104-1.2021v16n3p.27. ISSN: $1980-511 \mathrm{X}$

Resumo: Tendo em vista que o caráter axiológico do homem somado aos desdobramentos e avanços técnico-científicos dão azo a um questionamento ético, sobretudo considerando os acontecimentos históricos remetidos pelo Nazismo: a manipulação genética, embora cientificamente possível, é um caminho ético e seguro com vistas à preservação e persecução da dignidade humana? Desenvolve-se, assim, reflexões de cunho jusfilosófico no intuito de aferir as balizas da ciência médica em prol da conservação do decoro e da integridade do ser humano, analisando-se duas modalidades referentes à modificação no genoma - melhoramento genético e manipulação genética, e as variantes desta última, manipulação em células somáticas e manipulação em células germinativas. Para tanto, a metodologia fundamenta-se, precipuamente, na pesquisa bibliográfica e documental, bem como no exame legislativo. Ao final, conclui-se que a manipulação genética somática corresponde à manifestação da autodeterminação na constituição de uma vida digna, assegurada pela integridade física e psíquica do indivíduo, uma vez considerado que a ciência se encontra a serviço da humanidade na busca pela vida plena em detrimento da sobrevivência, de modo que a eugenia "negativa" vincula-se eticamente a um meio para vislumbrar o homem como um fim em si mesmo, restando-se desvinculada das perspectivas de superioridade racial.

Palavras-chave: Dignidade da pessoa humana; Ética; Estado Democrático de Direito; História; Manipulação genética.

Abstract: Bearing in mind that the axiological character of man 
added to developments and technical-scientific advances gives rise to an ethical questioning, especially considering the historical events referred to by Nazism: genetic manipulation, although scientifically possible, is an ethical and safe way with a view to preservation and pursuit of human dignity? Thus, reflections of a jusphilosophical nature are developed in order to gauge the beacons of medical science in favor of the preservation of the decorum and the integrity of the human being, analyzing two modalities related to the modification in the genome - genetic improvement and genetic manipulation, and variants of the latter, manipulation in somatic cells and manipulation in germ cells. To this end, the methodology is mainly based on bibliographic and documentary research, as well as on legislative examination. In the end, it is concluded that the somatic genetic manipulation corresponds to the manifestation of self-determination in the constitution of a dignified life, ensured by the physical and psychological integrity of the individual, since it is considered that science is at the service of humanity in the search for a full life in the detriment of survival, so that "negative" eugenics is ethically linked as a means to envision man as an end in itself, remaining unrelated to the perspectives of racial superiority.

Keywords: Dignity of human person; Ethic; Democratic state; History; Genetic manipulation. 


\section{INTRODUÇÃO}

Tendo em vista os acontecimentos ocorridos, principalmente, durante o Nazismo, vislumbra-se que a ética tem sua importância no contexto social uma vez que obsta a validação de práticas ilegítimas em nome da legalidade. Isso porque com o predomínio da técnica e da ciência, o positivismo levou à confusão entre a legalidade e a legitimidade, conferindo "amparo" às condutas misóginas e genocidas do Nazismo, em nome do que a "lei" permitia.

Assim, considerando que nem tudo que é realizável é ético, surge a problemática do presente trabalho: a manipulação genética, embora cientificamente possível, é um caminho ético e seguro com vistas à dignidade da pessoa humana?

Nessa lógica, justifica-se o estudo em razão do próprio momento em que se instaura. Partindo das recentes descobertas e inovações médico-científicas, a análise da medicina reprodutiva nunca se fez tão necessária sob ponto de vista ético e jurídico da manipulação genética, considerando as balizas incorporadas pela própria tutela da dignidade da pessoa humana.

Para tanto, utiliza-se o método dedutivo, partindo de premissas gerais, sendo empregadas no caso concreto ao passo que a metodologia utilizada se fundamenta, precipuamente, na pesquisa bibliográfica e documental, tendo como principais referenciais teóricos: Rita de Cássia Resquetti Tarifa Espolador; Heloisa Helena Barboza; Selma Rodrigues Petterle e Jürgen Habermas. Outrossim, partilha de exame legislativo de dispositivos nacionais.

Dividido em três partes, o artigo ocupa-se, em um primeiro momento, da construção histórica e da distinção entre eugenia, eugenética e eugenismo, perpassando pela importância da perspectiva histórica a fim de possibilitar as reflexões de cunho jusfilosófico.

Em seguida, os princípios bioéticos e seus reflexos na manipulação genética são analisados, uma vez que servem de baliza para o comportamento humano na seara da biotecnologia, sendo eles: autonomia, beneficência, não-maleficência e justiça. Outrossim, passa a versar acerca das formas de intervenção no genoma: manipulação versus melhoramento.

Por derradeiro, no último tópico, valendo-se da visão de Habermas como principal aporte teórico, busca-se a desconstrução do espectro do eugenismo a partir da perspectiva ética e histórica do direito, analisando se a manipulação genética representa amparo ou prejuízo para a proteção da dignidade humana.

\section{EUGENIA, EUGENÉTICA E EUGENISMO: CONSTRUÇÃO HISTÓRICA E DIFERENCIAÇÃO}

O caráter axiológico do homem somado aos desdobramentos e avanços técnico-científicos dão azo a um questionamento ético, sobretudo considerando os acontecimentos históricos remetidos pelo Nazismo: a manipulação genética, embora cientificamente possível, é um caminho ético e seguro com vistas à preservação e persecução da dignidade humana? Desenvolve-se, assim, 
reflexões de cunho jusfilosófico no intuito de aferir as balizas da ciência médica em prol da conservação do decoro e da integridade do ser humano.

Nesse sentido, merece destaque a lição de Eduardo Bittar (2002, p. 97), segundo a qual "[...] o lugar de discussões ocupado pela bioética é insubstituível, assim como o é o espaço ocupado pela ética filosófica". Embora a ética - como reflexão filosófica - tenha sido negligenciada e marginalizada com o racionalismo e utilitarismo imperante no século XX, tem-se que a "[...] ética e bioética convivem num mesmo espaço, sem se agredirem mutuamente, devendo a segunda [...] buscar acalento no seio da primeira [...], tudo no sentido de se fortalecer os conhecimentos [...]" (BITTAR, 2002, p. 97).

Salienta-se, nesse ínterim, que a compreensão do Direito somente é possível no contexto da civilização humana, e que a história possibilita a percepção do elaborar o Direito e as contribuições do passado para a construção do presente (GOMES, 2010, p. 156-157), de modo que, para possibilitar as reflexões de cunho jusfilosófico, é necessário realizar um levantamento histórico sobre o tema.

Ademais, a contextualização histórica é necessária tendo em vista a importância da visão panorâmica do fenômeno jurídico, alcançada e buscada pela Filosofia do Direito, uma vez que "há sempre uma resposta a problemas surgidos num determinado momento histórico" (COMPARATO, 2004, p. 5).

À vista disso, o século XIX restara marcado cientificamente pelo desenvolvimento de muitas teorias, dentre elas, os pensamentos evolucionistas e geneticistas arrazoados por Charles Darwin, Gregor Mendel, Matthias Schleiden e Theodor Schwann (TEIXEIRA; SILVA, 2017, p. 63-64), os quais deram azo à concepção eugênica, desenvolvida pelo cientista Francis Galton, concebida, a priori, como

Um programa de investigação científica, através de esforços conjugados provenientes da matemática, da estatística, da biologia e da antropologia com o firme propósito de fornecer uma teoria que compreendesse os mecanismos responsáveis pelo fenômeno da hereditariedade humana. (DEL CONT, 2013, p. 511)

Inspirado pelo livro "A origem das Espécies" de Charles Darwin, Galton buscou desenvolver um pensamento científico que obstasse a degeneração da espécie humana por meio de cruzamentos seletivos (TEIXEIRA; SILVA, 2017, p. 64), aplicando os pressupostos da seleção natural. Acreditava que as aptidões humanas estavam relacionadas à hereditariedade, sendo possível um aprimoramento genético dos "adequados". Segundo o mesmo,

As aptidões naturais de um homem são derivadas por hereditariedade [...] assim como é fácil obter por meio de cuidadosa seleção uma raça de cães ou cavalos dotada de capacidade peculiar para correr ou qualquer outra capacidade específica, seria também perfeitamente possível produzir uma raça de homens altamente dotada promovendo casamentos criteriosos ao longo de várias gerações consecutivas. (GALTON, 1979) 
Ocorre que essa ideia de melhoramento genético inaugurou um projeto de controle social, também calcado no eugenismo, que encontrou nos Estados Unidos da América seu berço e, na Alemanha seu incremento e vulgarização.

A Revolução Industrial e a migração para as vilas urbanas sucederam uma crescente criminalidade e marginalização social e, nesse contexto, o eugenismo se converteu em aspecto familiar dos norte-americanos, popularizando-se em concursos de "famílias mais aptas" e difundindo-se por meio de rádios, jornais e filmes.

A legalização da esterilização compulsória submetia cegos, epiléticos, surdos, deficientes mentais e desafortunados ao procedimento, "já que a pobreza tinha seu próprio diagnóstico médico: o pauperismo e, qualquer pessoa considerada um obstáculo para a sociedade estava em risco" (LANG-STANTON; JACKSON, 2017). Diante desse cenário, os movimentos eugênicos difundiam seu discurso de melhoramento de raça, pois acreditavam que o sucesso social tornava um indivíduo geneticamente melhor dotado, visto que

Nenhum tronco degenerado ou débil mental jamais poderá se tornar saudável e sólido pelos efeitos acumulados da educação, de boas leis e de um ambiente saudável. Isto equivaleria a apostarmos no meio ambiente em uma corrida em que a hereditariedade vence sem qualquer esforço. (PEARSON apud TEIXEIRA; SILVA, 2017, p. 64)

Finda a Primeira Guerra Mundial, a desestruturação econômica e urbana que assolou a Alemanha levou à aquiescência popular das ideias de "higienização racial" propagadas por Hitler, onde "o papel do mais forte era o de dominar e não de fundir-se com o mais fraco, sacrificando assim a sua própria grandeza" (HITLER apud BIZZO, 2013, p. 185-186). Com o holocausto nazista, o eugenismo tornou-se estigmatizado, difundindo a ideia de raça pura por todos os continentes.

No Brasil, a corrente do eugenismo teve origem em Raimundo Nina Rodrigues (LANG-STANTON; JACKSON, 2017), que eivado por um viés racista, propunha um melhoramento étnico, por meio da vedação à miscigenação entre brancos, negros e indígenas. As ideias segregacionistas foram institucionalizadas na América Latina, que sob uma roupagem de aprimoramento e progresso dos indivíduos, propagaram a discriminação e legitimaram atrocidades contra a dignidade e a integridade humana.

Com isso, verifica-se a importância da Constituição de 1988, que inaugura um novo conjunto de preocupações éticas, tendo em vista que a ordem jurídica constitucional possui o objetivo principal de alcançar a plenitude do convívio social pacífico, havendo normas jurídicas que são predispostas a produzir efeitos práticos sobre o comportamento e a conduta das pessoas (BITTAR, 2002, p. 99)

O preâmbulo da Constituição de 1988 afirma a instituição do Estado Democrático de Direito destinado a assegurar o exercício " [...] dos direitos sociais e individuais, a liberdade, a segurança, o bem-estar, o desenvolvimento, a igualdade e a justiça como valores supremos de 
uma sociedade fraterna, pluralista e sem preconceitos, fundada na harmonia social [...]” (BRASIL, 1988), protegendo a pessoa, independentemente de cor, etnia, religião e etc.

Feitas essas considerações, ao retomar o "eugenismo" percebe-se que o mesmo se consagra como ideia utópica e ideológica instituída sob a "convicção da possibilidade de substituição dos maus genes pelos bons, criando uma nova espécie de humanidade" (DINIZ, 2017, p. 626). Logo, o "espectro de eugenismo" (SCHRAMM, 1997, p. 2), ao ansiar por um ser humano "ideal", coisifica-o, abrindo espaço para o ressurgimento de uma medicina desumanizada, fundada na pureza racial e no resgate histórico nazifascista.

O termo eugenia, por sua vez, corresponde à ciência que investiga o aperfeiçoamento da reprodução humana e o aprimoramento genético do homem, por meio de uma expressão genérica que pode ser bipartida em eugenia positiva e eugenia negativa (SCHRAMM, 1997, p. 2).

Em primeiro plano, por uma corrente defendida por Fermin Roland Schramm e Maria Helena Diniz, a eugenia positiva "consiste no conjunto de conhecimentos científicos e medidas higiênico-sanitárias" (DINIZ, 2017, p. 625) que auxiliam na minimização de genes patogênicos e na geração de descendentes saudáveis. A eugenia negativa, por seu turno, "tem por escopo não só prevenir o nascimento de pessoa com patologia congênita, mas evitar a transmissão do gene defeituoso" (DINIZ, 2017, p. 625), por meio da erradicação de seus portadores, seja pelo aborto eugênico, morte de neonatos ou eutanásia.

Ante ao exposto, enquanto a eugenia positiva, por tal entendimento, avulta a redução de patologias hereditárias, buscando a melhoria da "dotação genética do ser humano" (DINIZ, 2017, p. 626) mediante modificações terapêuticas em seu genótipo; a eugenia negativa reforça a ideia de seres humanos selecionados, a partir da transmissão das novas características moldadas pela ciência aos descendentes, conferindo abertura ao surgimento de sujeitos geneticamente modificados.

Desse modo, considerando o significado contido na pessoa humana,

Consequentemente, inadmissíveis devem ser, não apenas quaisquer tentativas de intervenção no patrimônio genético defeituoso como também manipulações genéticas que procurem alterar a identidade genético-pessoal do indivíduo para a produção de seres humanos selecionados. É imprescindível que a dignidade humana seja preservada em qualquer fase da vida, inclusive na fetal. (DINIZ, 2017, p. 626)

Por fim, a eugenética, expressão contemporânea do termo eugenia, representa uma “tecnociência nascida nos anos 70, do encontro entre genética, biologia molecular e engenharia genética" (SCHRAMM, 1997, p. 1). Subdivide-se, igualmente, em eugenética negativa e positiva, entretanto, com significação voltada não à perpetuação da modificação genética à prole eventual e futura, mas com enfoque na natureza da manipulação. Negativa, quando voltada a fins terapêuticos, preditivos de patologias e, positiva, quando ansiar melhoramento das aptidões humanas, como inteligência, memória, estatura, cor dos olhos, sexo ou "outros caracteres psicofísicos" (DINIZ, 2017, p. 626). 
Ainda sobre tais distinções, faz-se mister salientar que a maioria dos doutrinadores, como Habermas, Selma Rodrigues Petterle, Fernando Mantivani e Carlos María Romeo Casabona não faz essa diferenciação, vez que se utilizam do termo "eugenia" como sinônimo de "eugenética" e, assim, a eugenia positiva e negativa teriam o mesmo significado de eugenética positiva e negativa. Portanto, a eugenia positiva corresponderia às alterações relacionadas à cor dos olhos, cabelo, estatura, por exemplo, ao passo que a eugenia negativa importaria na prevenção/tratamento de patologias. ${ }^{1}$

Por conseguinte, traça-se uma sólida linha de distinção entre os procedimentos autorizados e efetivados por intermédio da terapia genética da ideia de superioridade racial e melhoramento étnico, histórica e humanamente repudiada. Embora as expressões que nominam ambos os institutos partilhem de raiz comum, ${ }^{2}$ a carga axiológica da eugenética distancia-a cada vez mais do eugenismo, por objetivar mediante intervenção terapêutica e preditiva, assegurar a dignidade e o melhor interesse dos pacientes. Outrossim, imperiosa é a diferenciação entre a manipulação e o melhoramento gênico; pois ainda que controverso os limites da programação genética, inclusive dentre os pesquisadores mais tradicionalistas, axiomática é a aceitação da eugenética negativa, considerando seus desígnios e sua eficiência. Logo,

Um provável cenário do desenvolvimento de médio prazo poderia se apresentar da seguinte forma: na população, na esfera pública da política e na esfera parlamentar, impõe-se inicialmente a ideia de que o recurso ao diagnóstico genético de pré-implantação deve ser considerado por si só como moralmente admissível ou juridicamente aceitável, se sua aplicação for limitada a poucos e bem definidos casos de doenças hereditárias graves que não poderiam ser suportadas pela própria pessoa potencialmente em questão. (HABERMAS, 2004, p. 26)

A ciência insere-se na órbita jurídica como ferramenta auxiliadora do homem no exercício de sua dignidade, ao oportunizar técnicas de engenharia genética, métodos de reprodução assistida, terapias gênicas, conhecimento da identidade genética e tratamentos que aumentam a qualidade e prolongam o tempo de vida dos pacientes. Somente após compreender o caminho percorrido pelo sujeito, e inseri-lo no campo da dignidade e da autodeterminação, é possível interpretar a extensão do biodireito e sua confluência com a bioética. Estando a ciência a serviço do homem, e não o contrário, atestam-se os limites dos avanços biotecnológicos, vez que a humanidade intrínseca à natureza do ser deve corresponder ao objetivo máximo e único das pesquisas e procedimentos terapêuticos.

O imperativo técnico-científico vai, paulatinamente, cedendo espaço ao imperativo ético, emergindo novas ciências que têm como ponto central de reflexão a vida humana digna, personificando o progresso das descobertas, por analisar o homem como "um 'eu', dando valor fundamen-

1 No presente artigo, adota-se a corrente majoritária, de modo que eugenia negativa e eugenia positiva são termos utilizados como sinônimos, respectivamente, de eugenética negativa - termo vinculado a doenças/patologias - e eugenética positiva - termo vinculado às qualidades dos sujeitos.

2 Vem do grego eugenés, e significa "bem-nascido" (SCHRAMM, 1997, p. 1) 
tal à vida e à dignidade humana, não admitindo qualquer intervenção no corpo humano que não redunde no bem da pessoa, que sempre será um fim e nunca um meio para a obtenção de outras finalidades" (DINIZ, 2017, p. 30-31).

Diante do exposto, considerando a problemática do presente artigo - se a manipulação genética é ou não um caminho ético para a preservação e persecução da dignidade da pessoa humana - e tendo em vista já presenciada coisificação da vida, a exemplo do Nazismo, expor-se-ão, no tópico seguinte, os princípios bioéticos, utilizados como balizas para o comportamento ético na manipulação genética.

\section{PRINCÍPIOS BIOÉTICOS E SEUS REFLEXOS NA MANIPULAÇÃO GENÉTICA}

A ameaça científica sobre a humanidade introduziu uma série de regramentos de conduta para a adequação do desenvolvimento e progresso à ética, obstando abusos do biopoder e a coisificação do indivíduo por meio da geneterapia e das novas técnicas farmacológicas e biomédicas.

Sendo assim, o termo "bioética" foi, pela primeira vez empregado no ano de 1971, na obra Bioethics: bridge to the future, cuja autoria atribui-se ao norte-americano Van Rensselder Potter, enquanto ciência da sobrevivência, traduzindo um compromisso com o equilíbrio e a manutenção da vida no planeta (DINIZ, 2017, p. 34). Entretanto, há que se ponderar que em período anterior, mesmo desvalida dessa terminologia, a "semente" da bioética já se fazia presente no "meio" nazista, durante a realização de experiências em seres humanos (FIGUEIREDO, 2018, p. 495), na descoberta da estrutura tridimensional do ácido desoxirribonucleico e na evidenciação da primeira molécula de DNA recombinante (SCHAKER, 2017).

Nos tempos atuais à bioética se prende um ressignificado, atribuído a partir da $2^{\mathrm{a}}$ Edição de Encyclopedia of bioethics, 1995, como um "estudo interdisciplinar, ligado à ética, que investiga, na área das Ciências da Vida e da Saúde, a totalidade das condições necessárias a uma administração responsável da vida humana em geral e da pessoa humana em particular" (SAUWEN; HRYNIEWICS, 2000, p. 31), ou seja, relaciona-se à conduta médica, ante as descobertas científicas, na conservação das qualidades próprias e inatas ao homem.

No que se refere ao caráter principiológico da bioética, tem-se que a mesma passou a regulamentar-se, inicialmente, através de três princípios básicos - Belmont Report - quais sejam: (a) respeito pelas pessoas ou autonomia; (b) beneficência e (c) justiça (USA, 1979). Posteriormente a esses princípios fora acrescentada pela obra Principles of Biomedical Ethics, a não-maleficência, cuja qual passou figurar como quarto princípio (BEAUCHAMP; CHILDRESS, 2002, p. 143-144).

O primeiro a ser apresentado é o princípio da autonomia, de caráter teleológico, que reconhece o domínio do paciente sobre a própria vida e o respeito à sua intimidade, de modo que é requisitado do profissional da saúde o respeito da vontade do paciente. Decorrem desse princípio: a exigência do consentimento livre e informado e o modo de como tomar decisões de substituição quando o indivíduo não tiver autonomia suficiente (DINIZ, 2017, p. 39). Nesse sentido, 
Não pode o médico, a título de exemplo, impor ao paciente uma transfusão de sangue se esta não é aceita por sua religião (Testemunhas de Jeová). Obrigar a pessoa a este procedimento pode lhe causar danos psicológicos levando-a inclusive a uma depressão e exclusão do seu círculo social. Se a tecnologia deve vir para aumentar a qualidade de vida dos seres humanos, não se pode ignorar a vontade do indivíduo de reger sua vida conforme sua tábua de valores. (PAIANO; ROCHA, 2007, p. 131)

Quanto ao princípio da beneficência, também de caráter teleológico, baseia-se na tradição hipocrática de que o profissional da saúde só pode utilizar do tratamento para o bem daquele que está doente, e não para fazer o mal ou a injustiça. Requer o atendimento por parte do médico aos interesses dos sujeitos envolvidos, a fim de atingir seu bem-estar e, de consequência, evitando quaisquer danos (DINIZ, 2017, p. 39). Para Daury Cesar Fabriz (2003, p. 108), tal princípio deve servir como cenário para uma normatização jurídica cujo objetivo seja a possibilidade de sua compreensão em situações específicas, preceituando e assegurando direitos e deveres.

O princípio da não-maleficência, por sua vez, possui grande relação com o princípio anterior, eis que contém a obrigação de não provocar dano intencional pelos profissionais da saúde e decorre da máxima da ética médica: "primum non nocere" - primeiro, não prejudicar (DINIZ, 2017, p. 40). Conforme já citado, foi incluído posteriormente por Tom L. Beauchamp e James F. Childress, em 1979, e se difere do princípio da "beneficência" na medida em que visa não causar nenhum mal, enquanto este envolve ações de natureza positiva, como fazer o bem (BARBOZA, 2003, p. 55).

Por último, mas não menos importante, tem-se o princípio da justiça - desenvolvido com base na teoria sobre justiça social de Jonh Rawls - que demanda a imparcialidade na distribuição dos riscos e benefícios, no tocante à prática médica, tendo em vista que os iguais deverão ser tratados igualmente (ESPOLADOR, 2010, p. 190). É expressão da justiça distributiva, exigindo um vínculo equânime nos benefícios, riscos e encargos à saúde do paciente (DINIZ, 2017, p. 40).

Não obstante os princípios acima elencados não constituam normas precisas ou hierarquizadas e, de modo proposital, seu conteúdo seja vago, em torno deles há um consenso, o que lhes confere observância significativa (BARBOZA, 2003, p. 56). Nesse sentido, Claudia Loureiro $(2009$, p. 8$)$ expõe que os princípios bioéticos têm o dever de traduzirem-se em normas aptas a reger toda a atividade de aplicação, subsunção, interpretação ou elaboração de leis acerca das questões bioéticas, sendo que a fonte para esses princípios e regras é a Constituição Federal.

Nesse mister, as balizas éticas incutidas nos procedimentos envolvendo manipulação genética - balizas bioéticas - se fazem cada vez mais essenciais, sobretudo em razão do espaço ocupado pela ciência e medicina na sociedade moderna.

Quanto maior é o poder de manipulação da vida humana, maior é a necessidade de se impor limites éticos e jurídicos. Os assuntos que envolvem a Biotecnologia devem ser estudados e positivados com base em princípios amplos (qualitativos 
e limítrofes), abertos, não-absolutos, informados conjuntamente pelo Biodireito e pela Bioética para que reflexões críticas e respostas práticas sejam dadas em casos concretos, protegendo-se o bem estar coletivo, afastando-se o entendimento de que a ciência deve se pautar apenas por regras econômicas e mercadológicas, como dispõe o art. $6^{\circ}$ da Declaração sobre a Utilização do Progresso Científico e Tecnológico no Interesse da Paz e em Benefício da Humanidade. (ESPOLADOR, 2015, p. 72)

Feitas essas ponderações acerca dos princípios bioéticos a fim de ressaltar a proporção que os procedimentos envolvendo a manipulação de genes tem assumido, tem-se que os organismos vivos, em especial, seres humanos, apresentam características morfológicas, fisiológicas e comportamentais peculiares que, em regra, são sensorialmente visíveis ${ }^{3}$ ou/e perceptíveis mediante testes especiais, ${ }^{4}$ as quais denominam-se fenótipo. Esses traços extrínsecos originam-se da interação entre o meio de coexistência e a constituição genética dos homens e, não obstante "serem consideradas relativamente incólumes, ou não afetadas por condições ambientais normais, importante frisar que os genes estabelecem os limites dentro dos quais o ambiente pode modificar o fenótipo" (PETTERLE, 2007, p. 24-25).

Nesse contexto e, diante das preocupações relativas à identidade genética dos indivíduos, em 1990 iniciou-se, formalmente, nos Estados Unidos da América, o Projeto Genoma, que pretendia, em 15 anos "traçar a cartografia do código genético humano: conhecendo os genes, mapeando-os e associando-os a determinadas enfermidades" (PETTERLE, 2007, p. 27). O audacioso escopo desse projeto era a revelação das incógnitas humanas, propiciando um avanço na medicina e acarretando em uma maior e melhor qualidade de vida, minimizando o sofrimento humano e, atendendo o indiscutível anseio do homem, "o elixir da vida" (PETTERLE, 2007, p. 28).

Ocorre que essas discussões científicas em torno da constituição humana dão azo a dois caminhos opostos. O conhecimento do ser, se por um lado permite o avanço terapêutico em prol de tratamentos de maior eficiência, garantindo o bem-estar subjetivo, por outro, a detenção dessas informações inicia uma gananciosa corrida pelo monopólio genético, promovendo a "abertura de uma problemática ética e moral de grande magnitude, seja no plano individual, social ou político" (PETTERLE, 2007, p. 28). Logo, insere-se nas dubiedades humanas, "o desafio de também compreender o saber adquirido" (HONNEFELDER, 2003, p. 17).

Desse modo, acreditava-se que por meio desse Projeto, descobrir-se-ia o "santo graal" da ciência, mediante o sequenciamento do genoma, ao estabelecer a ordem das unidades químicas constitutivas do DNA. ${ }^{5}$ Não que seja totalmente falaciosa, entretanto essa determinação tornou plausível um caminhar vagaroso, porém contínuo rumo ao tratamento de inúmeras patologias, mas de forma alguma representou uma súbita e milagrosa cura para todas as disfunções humanas. Isto porque,

3 Como cor dos olhos, dos cabelos, da pele.

4 Tipo sanguíneo, por exemplo.

5 Essas unidades químicas são adenina $(A)$, guanina $(G)$, timina $(T)$ e citosina $(C)$, as quais determinam as características de um organismo. 
O desenvolvimento de uma pessoa caracteriza por uma sucessão contínua de eventos que ocorrem ao longo do tempo até a sua morte. O tipo de alimentação que recebe, o local onde vive, a família e o amor de que é objeto, os amigos, os sucessos, os fracassos, a sucessão de acontecimentos na sua vida, tudo isso tem importância na sua história e na maneira como vive e age. (ZATZ, 2007, p. 35)

Integrado à tríade "conhecer, prever e mudar", as questões afetas ao genoma apontam para as técnicas de alteração do DNA fundadas na terapia gênica e no aconselhamento genético. Tais procedimentos ambicionam a prevenção de distúrbios e anomalias genéticas, combatendo, pontualmente, o fato causal, seja pela alteração em células germinativas ou pela manipulação de células somáticas.

Permite-se, portanto, traçar uma diferença entre procedimentos envolvendo a manipulação de genes, com o intuito de "prevenir" e/ou "tratar" patologias, de procedimentos que tencionam alterar "qualidades", características humanas como estatura, cor dos olhos, cabelo, pele, etc. Enquanto aos primeiros adota-se a terminologia "manipulação genética", à segunda é tida como "melhoramento genético".

Diante dessa ressalva, no âmbito do "melhoramento genético" é possível a identificação de uma nova subdivisão, qualificada a depender da tipologia celular. Diante disso, a terapia gênica em células somáticas, por não perpetuar as alterações genéticas aos descendentes, é de modo razoável aceita, em sua grande maioria, pois, assim como as doenças são combatidas por intermédio de medicamentos, a manipulação desse tipo de célula comporta-se como um fármaco manejado sem desvios, contra a própria partícula.

No que concerne às células germinativas ou reprodutivas, em razão da alta capacidade de diferenciação, a sua utilização é coeficiente de grande discussão tanto na seara médica, quanto no campo jurídico e da pesquisa científica, desencadeando dois eixos de debate, "o primeiro centralizado nos efeitos dessas modificações nas gerações futuras, ainda desconhecidos e, o segundo, pelos estreitos vínculos dessa técnica com a eugenia" (PETTERLE, 2007, p. 35). Destarte,

A polêmica se estabelece porque a manipulação de células germinativas (gametas sexuais e células totipotentes dos embriões) interfere na constituição genética individual. A problemática que a terapia gênica em células germinativas suscita é bastante complexa porque, por vezes, não são muito claros os limites que separam a terapia gênica do melhoramento genético. (PETTERLE, 2007, p. 35)

Traçando um paralelo com os princípios bioéticos, defende-se o caráter "não ético" do melhoramento genético, sobretudo por representar uma espécie de "vitrine" humana, na qual os genitores poderiam "montar" as características de seus filhos a bel prazer, objetificando não apenas o ser humano, mas a própria vida e dignidade envolvida - eugenética positiva.

Quanto à manipulação genética de células germinativas, por seu turno, ao contrastar sobretudo com os princípios da beneficência e da não-maleficência, aponta-se para um campo duvidoso e incerto, vez que conforme aludido alhures, cada corpo reage e responde de maneira ímpar. 
Apesar de muito comparado com uma máquina, as "engrenagens" biológicas não seguem padrões únicos e contínuos.

Isto posto, o tópico seguinte se encarregará de examinar a manipulação genética de células somáticas à luz da intersecção entre o direito, história e a ética.

\section{DESCONSTRUÇÃO DO ESPECTRO DO EUGENISMO A PARTIR DA PERSPECTIVA ÉTICA E HISTÓRICA DO DIREITO}

O direito não é uma ciência estática e tampouco isolada. A ética e a história possuem, assim, grande relevância na construção e análise jurídica dos institutos, de tal sorte que a manipulação genética não foge ao padrão dessa lógica.

Tendo como ponto de partida a lição de que o que é aceito pela razão e pelo senso comum tende a mudar ao longo do tempo, ao mesmo tempo que a condição humana e os desafios por ela apresentados (BAUMAN, 2011, p. 10), o que denota mais uma vez a importância da perspectiva histórica no estudo jusfilosófico sobre a manipulação genética, passa-se à discussão propriamente dita sobre esta se tratar ou não de um caminho ético e seguro para a dignidade da pessoa humana. Seria a manipulação genética uma porta que não deve ser aberta? ${ }^{6}$

O linde conceitual entre a diligência preditiva fundada na promoção de tratamentos de patologias em uma fase intrauterina ou embrionária e a autotransformação da espécie a partir de decisões eugênicas perpassa por uma seara de ordem político-legislativa (HABERMAS, 2004, p. 30). Desse modo, a manipulação genética pode caminhar para a emancipação do homem a partir de sua autodeterminação, desde que essa delimitação entre prevenção e eugenismo velado reste-se bem delineada (HABERMAS, 2004, p. 41).

Não se pode esquecer que a consciência ético-jurídica dos povos se viu tocada pela necessidade de construção de um novo paradigma do Estado em razão das atrocidades praticadas contra milhões de pessoas pelo Estado totalitário, principalmente durante o regime nazista (GOMES, 2010, p. 275).

Nesse sentido, ressalta-se que o formalismo jurídico pode se colocar a serviço de qualquer finalidade quando não está comprometido com valores éticos que respeitem a dignidade humana, como aconteceu durante o regime Nazista (GOMES, 2010, p. 280).

No que toca à manipulação genética, ocorre que em muitos cenários, uma programação genética eugênica encontra-se maquiada pela ciência, para ter sua prática ética e legislativamente aceita. Diversamente dos tempos passados em que o conteúdo de pureza racial era propagado por um único arquétipo de autoritarismo, o eugenismo "liberal" tem sido semeado pelo acesso às informações e tangível pelo incremento médico-científico. Sendo assim,

\footnotetext{
6 De acordo com MARCHIONNI (2008, p. 40): “A biotecnologia, com sua capacidade de manusear a vida, pode, sim, melhorar a existência humana, mas pode também mudar a natureza humana e provocar a terra de Frankenstein. A sede humana de conhecimento e experimentação, a libido do saber, a ânsia de criar artificialmente a vida pretendem escancarar os mistérios. Existe uma porta que não se deve abrir?”
} 
While old-fashioned authoritarian eugenicists sought to produce citizens out of a single centrally designed mould, the distinguishing mark of the new liberal eugenics is state neutrality. Access to information about the full range of genetic therapies will allow prospective parents to look to their own values in selecting improvements for future children. Authoritarian eugenicists would do away with ordinary procreative freedoms. Liberals instead propose radical extension of them. (AGAR, 1999, p. 137)

Portando, na proporção em que o sujeito, "manipulado de forma eugênica, descobre seu corpo vivo também como algo fabricado, a perspectiva do participante da 'vida vivida' colide com a perspectiva reificante dos produtores ou artesões" (HABERMAS, 2004, p. 71), haja vista que, ao arbitrar sobre o conteúdo genético da prole, os genitores estabelecem parâmetros e listam expectativas, "sem, contudo, conceder ao seu destinatário, a possibilidade de uma reconsideração" (HABERMAS, 2004, p. 71)

A partir dessa compreensão do criado sobre o natural,

Quanto mais despreocupada for a intervenção na composição do genoma humano, tanto mais o estilo clínico do trato se aproxima do estilo biotécnico da intervenção e confunde-se a distinção intuitiva entre o que cresceu naturalmente e o que foi fabricado, entre o subjetivo e o objetivo - até atingir a auto referência da pessoa em sua existência corporal. (HABERMAS, 2004, p. 66)

Diante do exposto, os melhoramentos eugênicos obstaculizam a autonomia ética ao sujeitarem um indivíduo, desabastecido de consentimento livre e não viciado a projetos pré-determinados por terceiros, ainda que, seus responsáveis, impedindo a compreensão emancipada da sua própria essência. As práticas de aperfeiçoamento genético correspondem a um campo bastante longínquo da esfera de autoridade familiar, pois a determinação da composição biológica do ser em nada se relaciona à estrutura da autoridade parental. (HABERMAS, 2004, p. 69) ${ }^{8}$

Logo, a viabilidade trazida pela medicina contemporânea que resulta no "melhoramento" genético, por intermédio da seleção do sexo ou eleição de características qualitativas específicas, reflete na retirada da autonomia do homem e, em nada contribui para o desenvolvimento de sua identidade digna. Destarte, não há o que se falar em normatização da eugenia positiva ou, como alguns autores como Maria Helena Diniz, adeptos a uma classificação mais complexa, costumam conceituar por eugenética positiva, pois em uma sociedade "pluralista e democraticamente constituída, que concede a todo cidadão igual direito a uma conduta de vida autônoma, a seleção das disposições desejadas, a priori, não pode ser desatrelada do prejulgamento de determinados projetos de vida" (HABERMAS, 2004, p. 91)

\footnotetext{
7 Tradução livre: Enquanto eugenistas antiquados e autoritários procuravam produzir cidadãos a partir de um único modelo, a marca distintiva da nova eugenia liberal é a neutralidade do Estado. O acesso à informação sobre toda a série de terapias genéticas permite aos genitores que observem seus próprios valores ao selecionarem melhorias para os futuros filhos. Eugenistas autoritários suprimiriam as liberdades de procriação comuns. Já os liberais propõem a ampliação radical dessas liberdades.

8 Crítica trazida por Habermas, em relação a alguns pensadores que comparam as práticas eugênicas com a educação, dispondo que se os pais podem escolher como criarem seus filhos, a intervenção genética não seria menos legítima.
} 
Por fim, diferentemente desse "melhoramento", ao conceber que a liberdade eugênica dos pais não pode colidir com a autonomia ética dos filhos (HABERMAS, 2004, p. 69), tem-se que as práticas afetas à eugenia ou eugenética negativa, em nada se assemelham ao espectro do eugenismo. Seja sob a forma de um aconselhamento ou assumindo a roupagem de um diagnóstico, o tratamento terapêutico de uma disfunção, malformação ou patologia encontra-se plenamente desvinculado de toda e qualquer discriminação ou seleção racial.

Contudo, diante do caráter ético e histórico que se soma ao direito, apesar de desvincular a manipulação genética de práticas totalitárias - melhoramento genético -, a especificação da mesma a partir da tipologia celular tem o condão de aproximar ou distanciar os seres humanos de sua essência. Ao ser impossível - ao menos até o momento - prever o que a modificação em uma célula germinativa pode acarretar - transgenia - irrazoável se torna defender à luz da ética essa prática, especialmente por remeter, historicamente, pela ausência de certezas às experimentações nazistas.

Assim, a dignidade da pessoa humana, sua autodeterminação e integridade não apenas são conservadas a partir das terapias gênicas em células somáticas, mas são garantidas, de tal sorte que, sob o manto legislativo infraconstitucional e constitucional, ainda que de maneira esparsa e escassa, o ser humano tem em sua defesa o dever do Estado em promover o bem de todos, incluindo a saúde. Logo, guarnecida pela política pública, a medicina tem a seu favor o progresso científico, desde que o seu emprego não afaste o sujeito, eticamente, de sua humanidade.

Por conseguinte, o axioma da dignidade tem o árduo compromisso de acobertar, igualmente sob suas asas, o progresso em prol da saúde e os princípios éticos como forma de preservação do homem. Conclui-se, então, que os traços eugenênicos da programação genética não desnaturam as finalidades da terapia gênica nem a eiva dos pretextos para uma segregação racial. Pelo contrário, a manipulação em células somáticas não só auxilia, mas garante o exercício pleno da dignidade.

\section{CONCLUSÃO}

Diante do vertiginoso progresso externado, especialmente, pelo ramo da medicina, torna-se realidade palpável ao homem a manipulação genética. Nesse diapasão, a Bioética insere-se no ordenamento, atuando na tutela da dignidade e da autodeterminação ao sustar eventuais desarranjos científicos. Por meio da interpretação da biotecnologia a partir da perspectiva ética e histórica do direito, é possível desvencilhar as terapias genéticas do espectro do eugenismo, galgando rumo à dignidade da pessoa humana e da autodeterminação.

Após a análise da carga histórica atrelada ao eugenismo - experiências Nazistas - e da abordagem principiológica conferida à bioética, no artigo se explorou duas modalidades atreladas à modificação no genoma, a saber: melhoramento genético, manipulação genética, bem como as variantes desta última: manipulação em células somáticas e manipulação em células germinativas.

Nessa esteira, no último item, validaram-se as incertezas envolvendo o manuseio de célu- 
las germinativas e, as objeções ao "aperfeiçoamento genético" por representar um resgate velado dos ideais totalitários de melhoramento racial. A respeito das terapias gênicas em células somáticas, por seu turno, demonstrou-se que, que a medicina pode caminhar junto à ética e a história a fim de garantir o exercício pleno e máximo das potencialidades humanas, sem que isso recaia em uma robotização do ser humano.

Assim, a ciência encontra-se a serviço da humanidade na busca pela vida plena em detrimento da sobrevivência, de tal modo que a manipulação genética somática corresponde à manifestação da autodeterminação na constituição de uma vida digna, assegurada pela integridade física e psíquica do indivíduo. Logo, a eugenia "negativa" resta-se desvinculada das perspectivas de superioridade racial, acoplando-se eticamente a um meio para vislumbrar o homem como um fim em si mesmo.

\section{REFERÊNCIAS}

AGAR, Nicholas. Liberal Eugenics In: SINGER, Peter; KUHSE, Helga (org.). A companion to bioethics. Oxford: Blackwell, 1999.

BARBOZA, Heloisa Helena. Princípios do Biodireito. In: BARBOZA, Heloisa Helena; BARRETTO, Vicente de Paulo (org.). Novos temas de biodireito e bioética. Rio de janeiro: Renovar, 2003.

BAUMAN, Zygmunt. A ética é possível num mundo de consumidores? Tradução Alexandre Werneck. Rio de Janeiro: Zahar, 2011.

BEAUCHAMP, Tom L; CHILDRESS, James F. Princípios da ética biomédica. Tradução de Luciana Pudenzi. São Paulo: Edições Loyola, 2002.

BIZZO, Nélio. Meninos do Brasil: Ideias de reprodução, eugenia e cidadania na escola. São Paulo: Editora do Brasil, 2013.

BITTAR, Eduardo Carlos Bianca. Curso de ética jurídica: ética geral e profissional. São Paulo: Saraiva, 2002.

BRASIL. [Constituição (1988)]. Constituição da República Federativa do Brasil de 1988. Brasília, DF: Presidência da República, [2016]. Disponível em: http://www.planalto.gov.br/ ccivil_03/constituicao/constituicao.htm. Acesso em: 21 jan. 2021.

COMPARATO, Fabio Konder. O direito como parte da ética. In: ALVES, Alaôr Caffé; et. al. O que é a filosofia do direito? Barueri: Manole, 2004.

DEL CONT, Valdeir. O controle de características genéticas humanas através da institucionalização de práticas socioculturais eugênicas. Scientiae Studia, São Paulo, v. 11, n. 13, p. 511-530, 2013. Disponível em: http://www.scielo.br/pdf/ss/v11n3/04.pdf. Acesso em: 02 
jan. 2021.

DINIZ, Maria Helena. O estado atual do biodireito. 10. ed. São Paulo: Saraiva, 2017.

ESPOLADOR, Rita de Cássia Resquetti Tarifa. Manipulação genética humana: o controle jurídico da utilização de embriões em pesquisas científicas. 2010. 251f. Tese (Doutorado em Direito das relações Sociais) - Universidade Federal do Paraná, Curtiba, 2010.

ESPOLADOR, Rita de Cássia Resquetti Tarifa. Alguns apontamentos sobre a lei de biossegurança nos negócios biojurídicos envolvendo a manipulação genética humana. In: ARAUJO JUNIOR, Miguel Etinger de; AMARAL, Ana Cláudia Corrêa Zuin Mattos do. (org.) Estudos em direito negocial: relações privadas e direitos humanos. São Paulo: Boreal Editora, 2015.

FABRIZ, Daury Cesar. Bioética e direitos fundamentais: a bioconstituição como paradigma ao biodireito. Belo Horizonte: Mandamentos, 2003.

FIGUEIREDO, Antônio Macena. Bioética: crítica ao principialismo, Constituição brasileira e princípio da dignidade humana. Revista Bioética, Brasília, v. 26, n. 4, p. 494-505, 2018. Disponível em: http://revistabioetica.cfm.org.br/index.php/revista_bioetica/issue/view/67. Acesso em: 28 dez. 2020.

GALTON, Francis. Hereditary Genius: an inquiry into its laws and consequences. Londres: Julian Friedmann, 1979.

GOMES, Sergio Alves. Hermenêutica constitucional: um contributo à construção do Estado Democrático de Direito. Curitiba: Juruá, 2010.

HABERMAS, Jürgen. O futuro da natureza humana: a caminho de uma eugenia liberal? São Paulo: Martins Fontes, 2004.

HONNEFELDER, Ludger. Perspectivas da tecnologia genética: um desafio para a ética. In: SOUZA, Draiton Gonzaga de; ERDTMANN, Bernardo (org.). Ética e genética II. Porto Alegre: EDIPUCRS, 2003.

LANG-STANTON, Peter; JACKSON Steven. Eugenia: como movimento para criar seres humanos 'melhores' nos EUA influenciou Hitler. BBC News/Brasil, Londres, 23 abr. 2017. Disponível em: https://www.bbc.com/portuguese/internacional-39625619. Acesso em: 04 jan. 2021.

LOUREIRO, Claudia Regina de Oliveira Magalhães da Silva. Introdução ao biodireito. São Paulo: Saraiva, 2009.

MARCHIONNI, Antônio. Ética: a arte do bom. Petrópolis: Vozes, 2008.

PAIANO, Daniela Braga; ROCHA, Maurem da Silva. Biodireito e início da vida: crise de paradigmas no ordenamento jurídico brasileiro. Intertemas, Presidente Prudente, v. 12, p. 123- 
$140,2007$.

PETTERLE, Selma Rodrigues. O direito fundamental à identidade genética na constituição brasileira. Porto Alegre: Livraria do Advogado, 2007.

SAUWEN, Regina Fiuza; HRYNIEWICS, Severo. O Direito "in vitro" - Da bioética ao biodireito - Temas Polêmicos. 2. ed. Rio de Janeiro: Lumen Juris, 2000.

SCHAKER, Patrícia. Tecnologia do DNA recombinante: histórico, enzimas de restrição, vetores e eletroforense. 2017. Disponível em: https://edisciplinas.usp.br/pluginfile.php/4113623/ mod_resource/content/1/Aula\%204\%20-\%20Tecnologia\%20DNA\%20recombinante_ enzimas\%20de\%20restri\%C3\%A7\%C3\%A3o.pdf. Acesso em: 20 jan. 2021.

SCHRAMM, Fermin Roland. Eugenia, eugenética e o espectro do eugenismo: considerações atuais sobre biotecnociencia e bioética. Revista Bioética, Brasília, v. 5, n. 2, 1997. Disponível em: http://revistabioetica.cfm.org.br/index.php/revista_bioetica/article/view/384. Acesso em: 08 jan. 2021.

TEIXEIRA, Izabel Mello; SILVA Edson Pereira. História da eugenia e ensino da genética. História da ciência e ensino: construindo interfaces, v. 15, p. 63-80, 2017. Disponível em: https://revistas.pucsp.br/index.php/hcensino/article/viewFile/28063/22596. Acesso em: 13 jan. 2021.

USA. Office For Human Research Protections. U.S. Department Of Health \& Human Service. The Belmont report. 1979. Disponível em: https://www.hhs.gov/ohrp/regulations-and-policy/ belmont-report/read-the-belmont-report/index.html. Acesso em: 08 dez. 2020.

ZATZ, Mayana. Genética: escolhas que nossos avós não faziam. São Paulo: Globo, 2011.

Como citar: FERRARI, Melissa Mayumi Suyama; ESPOLADOR, Rita de Cássia Resquetti Tarifa. Dignidade humana e manipulação genética: reflexões jusfilosóficas acerca da modificação do genoma. Revista do Direito Público, Londrina, v. 16, n. 3, p. 27-43, dez. 2021. DOI: 10.5433/24157-108104-1.2021v16n3p.27. ISSN: 1980-511X

Recebido em: 23/08/2021

Aprovado em: 18/11/2021 